The Physics of the Divining Rod

Being an Account of an Experimental Investigation of Water and Mineral Divining. By J. Cecil Maby and T. Bedford Franklin. Pp. $\mathrm{xv}+452+6$ plates. (London: G. Bell and Sons, Ltd., 1939.) 21s, net.

7 HIS is a very ambitious book: its aim is to provide a much-needed physical explanation of dowsing and to improve its technique on scientific lines and, at the same time, to present a coherent mathematical theory. The greater part of the book is written by the first author and surveys the whole field of former investigations, describing many others made by himself and his co-workers. In his survey Mr. Maby shows a very uncritical acceptance of a number of claims either very insecurely established or already discredited. This has an unfortunate effect on the scientific reviewer, and his confidence is not increased by finding that there is not a graph containing points which indicate actual observations : all are smoothed means and consequently their value cannot be assessed. Measurements with WynnWilliams ionization counters are described but not in sufficient detail to make critical comment possible. Atmospheric ionization is not an easy subject experimentally.

The theoretical section, by the second author, postulates some form of cosmic radiation resulting in electromagnetic waves of ten metres wave-length. There seems to be no direct evidence for such waves, and the author's discussion of their polarization cannot be justified on our present physical knowledge.

In presenting facts and theories to the scientific world, there is a well-accepted and necessary procedure. It is to be regretted that the authors have not followed this procedure, thus making the position of the scientific reviewer impossible.

\section{Fossil Orthoptera Ensifera}

By Frederick Eberhard Zeuner. Text. Pp. xiii +321 . 15s. Plates. Fp. iv +80 . 20s. (London: British Museum (Natural History), 1939.)

D. ZEUNER has written a monograph which transcends the immediate purpose of a British Museum catalogue. He has made a study of fossil Orthoptera and allied insects side by side with the recent species and, in this way, he has enabled the reconstruction with reasonable probability of the evolution of the group Ensifera. This latter assemblage includes the Tettigoniidæ, or longhorned grasshoppers, the Gryllidx, or crickets, together with various allied families. It is shown that the Ensifera may be traced back into Upper Carboniferous rocks. Their ancestors were Protorthoptera and are closely related to those of the Acridian group or short-horned grasshoppers.

Dr. Zeuner is an expert at his task and, unlike some insect palæontologists, he has the knowledge neec ssary to combine the evidence derived from recent and fossil forms to good purpose. Passing over the purely technical descriptions of genera and species, the premises upon which the main conclusions are based form interesting and instructive reading. The author's accounts of the venation and of the sound- receptor organs, for example, have involved a large amount of independent investigation the results of which aid in solving the phylogeny of the insects concerned. We hope that the British Museum (Natural History) will see its way in future to publish more monographs, of larger or smaller groups, involving, like the present work, conclusions of fundamental importance to our understanding of their origins and affinities.

\section{Buschi}

Vom Orang-Säugling zum Backenwülster. Von Prof. Dr. G. Brandes. Pp. v+135. (Leipzig: Quelle und Meyer, 1939.) 4.80 gold marks.

"BUSCHI" is a somewhat discursive account of the B growth of a celebrated male orang-utan belonging to the Dresden Zoological Gardens, to which it went when an infant a few weeks old, and where it is apparently still living, a mature and powerful ape enjoying, judging by its photog:aphs, even less in the way of good looks than is normally possessed by orangs. Records are given of the animal's in. creasing weight, of the times of eruption of its teeth, of its soxual maturation, and its development of secondary sexual characters; much of this information is of considerable interest to students of human evolution. Dr. Brandes has also gone to great trouble in acquainting himself with, and in illustrating, the individual characteristics of other captive orangs, and his observations on the great variability of this species of ape are not without interest in relation to the general question of racial differentiation, and in particular with the more specific question of the existence or non-existence of races among orangs. The book is lavishly illustrated, bu $\lrcorner$ it has no bibliography.

Monograph of the South American Weevils of the Genus Conotrachelus

By Karl Fiedler. Pp. iv + 365. (London: British Museum (Natural History), 1940.) 15s.

THIS work, the text of which is written in German, deals with a single genus of weevils that is extremely numerous in species. It is entirely devoted to descriptions of the South American members and the majority of these refer to new species. The genus includes a number of forms that are pests of cacao, custard apple, guava, together with certain Leguminosae and such fruits as plums, apricots, etc. The monograph is illustrated by ore plate and various text figures.

\section{Statistical Method from the Viewpoint of Quality Control}

By Dr. Walter A. Shewhart, with the editorial assistance of Dr. W. Edwards Deming. Pp. $\mathrm{x}+\mathbf{1 5 6}$. (Washington, D.C.: Graduate School, Department of Agriculture, 1939.)

GOR many years Dr. Shewhart has concerned himself with the development of statistical methods in the practical business of quality control in mass production. This latest publication covers old ground and provides a didactic foundation rather than any new extensions of his previous ideas. R. A.F. 